\title{
DESIGN AND EXPERIMENTAL ANALYSIS OF A SOLAR
}

\section{DESALINATION SYSTEM}

\author{
R. MURUGAN ${ }^{1}$, G. SIVARAMAN ${ }^{2} \&$ V. SURESH ${ }^{2}$ \\ ${ }^{1}$ Research Scholar, Department of Mechanical Engineering, Sona College of Technology, \\ Anna University, Salem, Tamil Nadu, India \\ ${ }^{2}$ Assistant Professor, Department of Mechanical Engineering, Sona College of Technology,
}

Anna University, Salem, Tamil Nadu, India

\section{ABSTRACT}

The distillation is one of the important methods of getting clean water from brackish and seawater using the free energy supply from the sun. Drinking Water consumption has been increasing with an ever increasing population. Availability of people water is going to become one of the most pressing resource issues in the future.

An experimental work is conducted on a single slope solar still. The thermal performance of the single slope solar still is examined and evaluated through implementing the following effective parameters a) water depth of 1 cm, 3cm and $5 \mathrm{~cm}$; b) solar intensity; c) ambient, water, and Vapour temperatures; d)with and without heat storage (stone) medium. Different effective parameters should be taken into account to increase the still productivity.

Results showed that still productivity is increased by decreasing the depth from higher to lower. Also, it is observed that still productivity is decreased by increasing the salt content. However, still, productivity is significantly increased by using heat storage medium (stone) compared to that of with heat storage medium.

KEYWORDS: Solar Still, Design Modifications, Thermal Performance \& Heat Storage

Received: Jun 22, 2018; Accepted: Jul 13, 2018; Published: Aug 14, 2018; Paper Id.: IJPRDEC20182

\section{INTRODUCTION}

The literature review of solar water heaters shows that that the different type of solar desalination system have been investigated experimentally under different systems and operating conditions by several researchers.

Julián Blanco Galveza et. al discussed the technology to be developed within the framework of MEDESOL project: Could provide sustainable development even to remote areas where the electric grid is unreliable or not available. Could increase the efficiency of solar desalination based on MD in comparison to existing pilot plants. They Could be cost-effective compared to conventional medium-range capacity solar distillation systems: solar multi-stage flash distillation and solar multi-effect distillation). (1).

Shaobo Houa et al studied that the two-stage solar multi-effect humidification- dehumidification desalination process has a higher energy recovery rate than the one stage does. In an extreme case, the minimum temperature difference at pinches are $1^{\circ} \mathrm{C}$, the energy recovery rate could reach 0.836 . If using multistage, the energy recovery rate would be higher, and that lead a higher GOR. The multi-effect HDD has much room to be improved. (2) 
Yasser Fathi Nassar et. al studied the various performance of the roof-type solar still, and the main points of our conclusions are as following a) the reduction in power required to produce $1 \mathrm{~kg}$ of fresh-water will be $90.1 \%$, b) The improvement in the performance ratio PR will be $90 \%$. will be $20.11 \mathrm{~kg} / \mathrm{m} 2 \mathrm{~d}$, compared with the most effective existing solar still productivity of $5 \mathrm{~kg} / \mathrm{m} 2 \mathrm{~d}$. c) Economically the excess in productivity will lead to reducing the unit cost of the water. d) Furthermore, the vacuum pump in the still, may be operated by means of photovoltaic system to provide the rural villages with drinkable water. (3)

Fawzi Banata et. al the Seawater was successfully fed to the unit without any chemical pretreatment; saving the costs and dangers of chemicals usually used in the RO processes. A thermal storage tank and a battery bank were implemented to store thermal and electrical energy for extra operating hours after sunset. Condensation of the permeate vapor allows heat recovery of the captured energy. This substantially increased the energy efficiency and hence the drinking water output rate. The results show that the output from the unit was in the range of 2 to $11 \mathrm{~L} / \mathrm{day} / \mathrm{m} 2$ ap. Area with specific energy consumption in the range of $200-300 \mathrm{kWh} / \mathrm{m} 3$. (4)

Omar O. Badran et. al studied the several conclusions can be obtained as follows; (a) the increase in either ambient temperature and/or the solar intensity can lead to an increase the solar productivity, (b) as the water depth decreases from $(3.5 \mathrm{~cm})$ to $(2 \mathrm{~cm})$, the productivity increases by $(25.7 \%)$, (c) The maximum efficiency occurs in early afternoon due to the high solar radiation at this time, (d) the overall heat loss coefficient increases until it reaches the maximum in the afternoon due to higher solar intensity and ambient temperature, and finally, (e) the proposed mathematical model gave good match with experimental results. Future work can be carried out using this model to enhance the design of single solar stills. (4)

Hazim Mohameed Qiblawey et. al discussed with focusing on those technologies appropriate for use in remote villages. Solar energy coupled to desalination offers a promising prospect for covering the fundamental needs of power and water in remote regions, where connection to the public electric grid is either not cost effective or not feasible, and where the water scarcity is severe. Solar desalination processes can be devised in two main types: direct and indirect collection systems. The direct solar energy method uses a variety of simple skills which are appropriate for very small water demands; indirect methods use thermal or electrical energy and can be classified as: distillation methods using solar collectors or membrane methods using solar collectors and/or photovoltaics for power generation. (5)

Hassan E. S. Fatha et. al described the desalination unit based on membrane distillation is given. The unit is self-operating using a PV panel to run the feed pump and solar collectors to heat up the feed water. Condensation energy is recovered in the condenser channel of the membrane to preheat the feed water. A sample of the measurements for a clear day and a cloudy day is presented and indicates a high productivity of $11.2 \mathrm{l} / \mathrm{m} 2$. $\mathrm{d}$ for a total solar energy of $7.25 \mathrm{kWh} / \mathrm{m}^{2}$. d. A correlation between the unit productivity and total solar radiation is given. The unit shows a high salt rejection performance as it reduced the electric conductivity of the feed water from 670 to about $3 \mu \mathrm{S} / \mathrm{cm}$, for the product. This gives a salt rejection percentage of about $99.5 \%$. The MD process efficiency is about $90 \%$ and the solar collector efficiency is about $50 \%$. (6)

From the above, author's discussions in various aspects of desalination process have been studied, and that can be improved by the means of design variables and heat storage medium (stone). 


\section{SOLAR DESALINATION SYSTEM}

Basic solar stills can be used to purify water in remote regions where contaminated water is present. They can be used to remove impurities such as fluoride and salts to produce drinking water. The basic still is made of a glass or transparent plastic cover and a shallow tray of water which has a black backing to trap energy. When the sun heats the water up within the still water evaporates which then condenses on the underside of the covering glass. The glass is at an angle so the water drains off and is captured in a trough separate to the contaminated water. Solar distillation can be combined with other useful functions so that a solar still may also be used for rainwater harvesting if modified slightly.

\subsection{Principle of the Solar Desalination System}

Solar desalination is a technique to desalinate water using solar energy. Distillation is the separation of a liquid from other liquids or solids. Because each substance has a fixed rate of Vaporization (which varies with heat) -- determined by the pressure the Vapour develop in a closed container to achieve equilibrium with the fluid -- one liquid can be separated from other matter by carefully controlling the heat applied to the mixture. Alcohol's Vapour pressure happens to be higher than water's, so ethanol's Vapour pressure reaches an equilibrium with atmospheric pressure (the point at which a liquid boils) before water's Vapour pressure does.

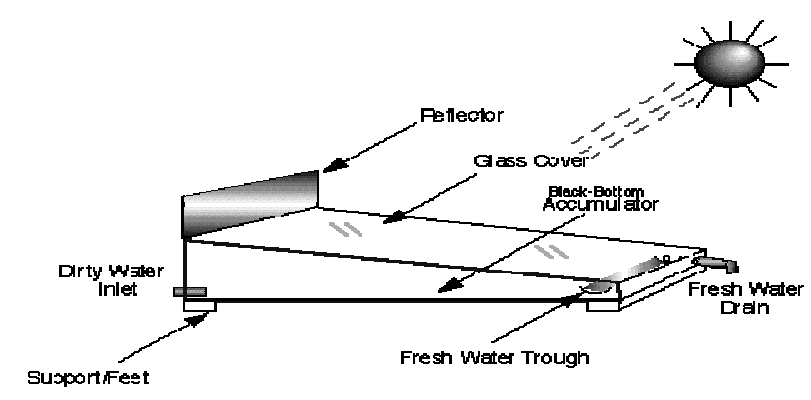

Figure 1

\section{EXPERIMENTAL SETUP}

The basin liner is made of the copper sheet of $900 \times 400 \times 50 \mathrm{~mm}$ and $1.5 \mathrm{~mm}$ thickness. The copper sheet was painted by red-lead primer then by matt-type black paint. There are certain specifications needed for the used glass cover in the still, and they are a minimum amount of absorbed heat, a minimum amount of reflection for solar radiation energy, the maximum transmittance for solar radiation energy, and high thermal resistance for heat loss from the basin to the ambient.

Glass covers have been sealed with silicon rubber which plays an important role to promote efficient operation as it can accommodate the expansion and contraction between dissimilar materials. Thermo cool of $2.5 \mathrm{~cm}$ thickness with the thermal conductivity of $0.045 \mathrm{~W} / \mathrm{m} \mathrm{K}$ is used as an insulating material to reduce the heat losses from the bottom and the side walls of the solar still. A small feeding tank is installed in the system as a constant head tank which is used to control the level of water inside the still (maintain the water level in the basin constant along time) by a floating ball. Then the outer box made of plywood. 


\subsection{Experimental Setup with and without Heat Storage (Stone) Medium}
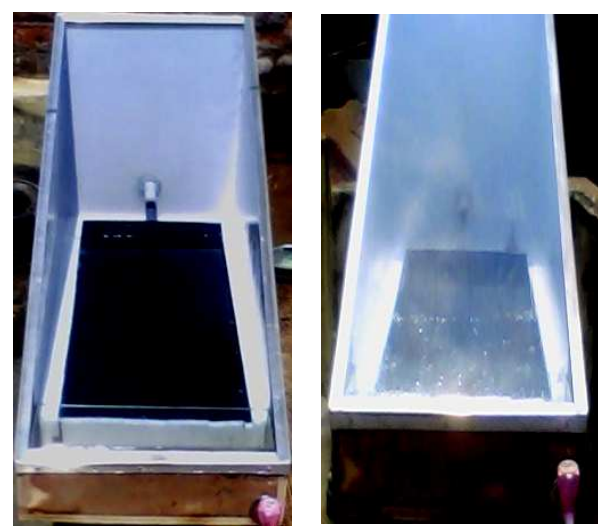

Figure 3.1: Solar Still with and without Heat Storage

Figure 3.1 shows the setup with and without the stone medium of the still basin. Various aspects such as temperature, productivity to be measured once every hour And also the percentage of salt concentration is added to water like $0 \%, 10 \%$, and $20 \%$ depending upon the water depth into the still basin. The different water levels of the basin are $1 \mathrm{~cm}$, $3 \mathrm{~cm}$ and $5 \mathrm{~cm}$.

When sun radiation is coming on the solar still so glass cover is heated. And due to the heating of glass cover temperature of the water inside the solar still is increased and it forms Vapour. Such Vapour has low density so goes upward and stick to glass cover means it condenses. And due to slope it will go downward and collect in the glass. The water produced due to solar still is called pure water.

\subsection{Specifications}

Table 1

\begin{tabular}{|l|l|c|l|}
\hline \multicolumn{1}{|c|}{ Parts Name } & Material & Size & Purpose of Selection \\
\hline Still outer box & plywood & 1130 X 500 X 650mm & Low cost and stability \\
\hline Still Basin & Copper sheet & 400 X 900 X 60 mm Thickness 1.5mm & High heat conductivity \\
\hline Top Glass Cover & Glass & $1230 \times 500 \times 4 \mathrm{~mm}$ & High transmitivity \\
\hline Thermo cool & Thermo cool & $25 \mathrm{~mm}$ thick & Insulation, low cost \\
\hline
\end{tabular}

\subsection{Parts Drawing}
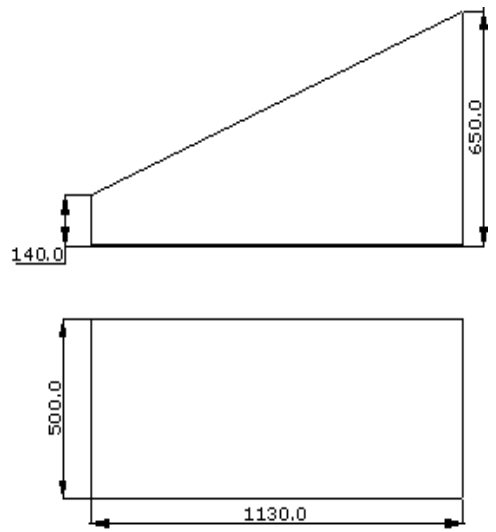

All Dimensions are in ' $m$ m'

Figure 3.2: Outer Box 
Material: Wood
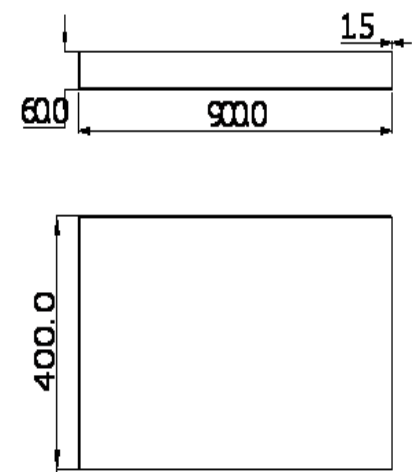

All Dimensions are in ' $m$ '

Figure 3.3: Still Basin

Material: Copper

Thermal conductivity: $386 \mathrm{~W} / \mathrm{mK}$

Specific heat: $385 \mathrm{~kJ} / \mathrm{kgK}$

Density: $8954 \mathrm{~kg} / \mathrm{m}^{3}$

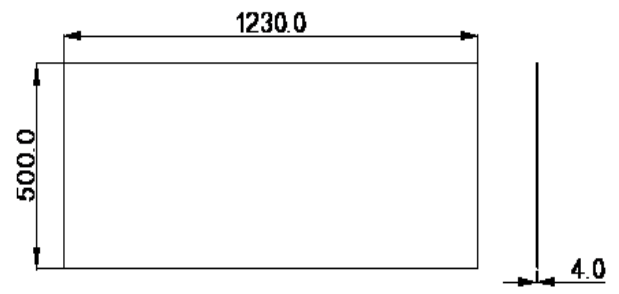

Figure3.4: Glass Cover
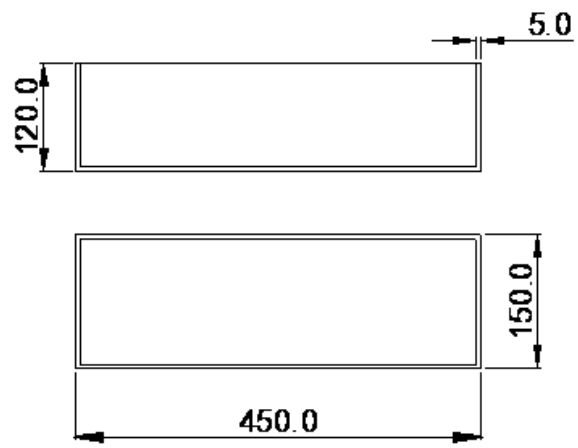

Figure 3.5: Collecting Tank

\subsection{Measuring Techniques}

The solar still is operated from 6:00 am to 6:00 pm during the months of April and May 2017. The measurements of the temperatures, solar radiation intensity, and the production of distilled water are taken hourly to study the effect of each parameter on the still productivity. In this study, various operating conditions have been examined such as; different water depth, insulation thickness, ambient temperature. The variables such as Tgin, Tgout, Ta, Tw , Tp and productivity were measured hourly. The total productivity and solar Intensity for each day were also measured. Also, different 
experimental tests were carried out under different ambient conditions. From about 2 pm, water temperature decreases due to the losses from the solar still which becomes larger than the absorbed solar radiation. It can be noted that the basin temperature gets closer to the water temperature because of the continuous contact between them which lead to heat equilibrium.

As the glass temperature is much smaller than the vapor temperature, it causes condensation of vapor on the glass. In the early hours of the morning (8-9 am), the glass temperature is higher than the water and Vapor temperatures causing small productivity due to the small energy absorbed by the water at these times. Increase in the solar intensity in the early morning until it reaches the maximum at around 12 and $13 \mathrm{pm}$, then decreases in the late afternoon. The solar intensity has an important effect on the solar still productivity. As the solar intensity increases, the productivity increases due to the increase in heat gain for water Vaporization inside the still.

The productivity rate varies as time passes from early morning until late afternoon. In the morning, the temperature of the water is low; therefore it needs high energy to change its phase from saturated liquid to saturated Vapour phase. The results show that temperature and required heat are inversely proportional. In the early afternoon the temperature of water reaches the maximum so it needs less heat to Vaporize, and vice versa in the late afternoon.

\section{SOLAR STILL EFFICIENCY AND PRODUCTION}

\subsection{Solar Still Efficiency $(\eta)$}

It is the amount of energy utilized in vaporizing water in the still over the amount of incident solar energy on the still. These can be expressed as below,

Solar still efficiency: $\eta=Q$ e $/$ Qt

Where,

Qe - Amount of energy utilized in vaporizing water in the still in $\mathrm{J} / \mathrm{m} 2$ day.

Qt - Amount of incident solar energy on the still in $\mathrm{J} / \mathrm{m}^{2}$ day.

\subsection{Solar Still Production (Me)}

It is the amount of energy utilized in vaporizing water in the still over the latent heat of vaporization of water.

Solar still production: $\mathrm{M}$ e $=\mathrm{Q}$ e $/ \mathrm{L}$ in $\mathrm{kg} / \mathrm{m} 2$ day.

Where,

Qe - Amount of energy utilized in vaporizing water in the still in $\mathrm{J} / \mathrm{m} 2$ day.

L- Latent heat of vaporizing of water in $\mathrm{J} / \mathrm{Kg}$. 


\section{RESULTS AND DISCUSSION}

\subsection{With Heat Storage Medium (1cm Depth)}

Table 5.1: $1 \mathrm{~cm}$ Depth (3.6 lit of Water with 0\% Salt Concentration)

\begin{tabular}{|c|c|c|c|c|c|}
\hline $\begin{array}{l}\text { Time } \\
\text { (Hrs) }\end{array}$ & $\begin{array}{c}\text { Ambient } \\
\text { Temp }\left(T_{a}\right) \\
{ }^{\circ}\end{array}$ & $\begin{array}{l}\text { Glass Inside } \\
\text { Temp }\left(\mathrm{T}_{\text {gin }}\right)^{\circ} \mathrm{c}\end{array}$ & $\begin{array}{l}\text { Glass Outside } \\
\text { Temp }\left(\mathbf{T}_{\text {gout }}\right){ }^{\circ} \mathrm{c}\end{array}$ & \begin{tabular}{|c|} 
Plate \\
$\underset{\text { Temp }}{{ }^{\circ} \mathbf{c}}\left(\mathbf{T}_{\mathbf{p}}\right)$ \\
\end{tabular} & $\begin{array}{c}\text { Water } \\
\text { Temp } \\
\left(\mathrm{T}_{\mathrm{w}}\right)^{\circ} \mathrm{c}\end{array}$ \\
\hline 6 & 27.8 & 28 & 28.9 & 28 & 27.9 \\
\hline 7 & 34.1 & 31.2 & 34 & 33.8 & 34 \\
\hline 8 & 34.7 & 34 & 34.8 & 35.1 & 35.6 \\
\hline 9 & 35.8 & 38.2 & 38.4 & 40.8 & 41 \\
\hline 10 & 37 & 46.1 & 39.1 & 49.8 & 51.3 \\
\hline 11 & 39.6 & 53.4 & 42 & 56.1 & 60.8 \\
\hline 12 & 42.1 & 61.5 & 45.6 & 66.2 & 68.7 \\
\hline 1 & 43 & 66 & 48 & 70.3 & 73 \\
\hline 2 & 44.5 & 68.1 & 49.2 & 73.1 & 77.2 \\
\hline 3 & 41.2 & 58.1 & 43.4 & 60.4 & 64 \\
\hline 4 & 38.1 & 48.2 & 40.2 & 52.4 & 58.6 \\
\hline 5 & 37.6 & 44 & 39.1 & 48.1 & 50.2 \\
\hline 6 & 35 & 39 & 36.3 & 42.5 & 45.1 \\
\hline
\end{tabular}

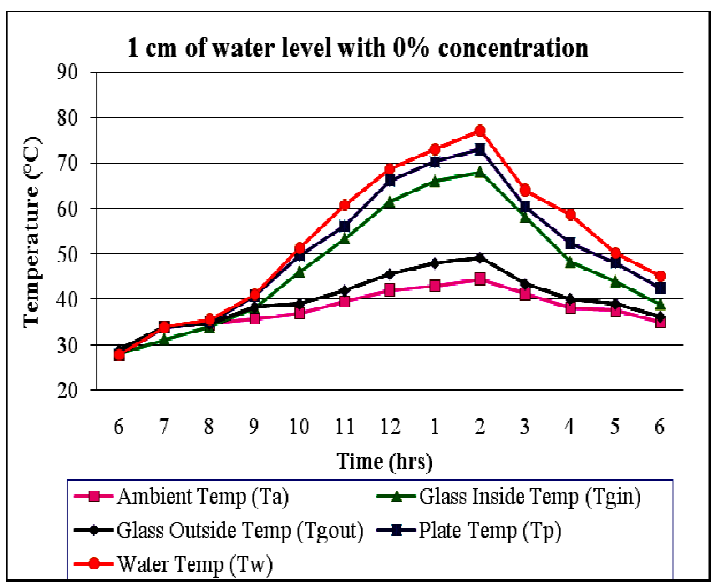

Figure 5.1: Temperature Vs Time for $0 \%$ Salt Concentration (1cm Depth)

Figure 5.1 shows that variation of temperature and time for $1 \mathrm{~cm}$ of water level with $0 \%$ concentration. It can be seen that an increase in the water temperature occurs until it reaches the maximum in the afternoon because the absorbed solar radiation exceeds the losses to the ambient. From about $2 \mathrm{pm}$, water temperature decreases due to the losses from the solar still which becomes larger than the absorbed solar radiation. It can be noted that the system with heat storage (stone) medium. The maximum temperature of the water is $77.2^{\circ} \mathrm{c}$

\subsection{With Heat Storage Medium (3cm Depth)}

Table 5.2: $3 \mathrm{~cm}$ Depth (10.8 lit of Water with 0\% Salt Concentration)

\begin{tabular}{|c|c|c|c|c|c|}
\hline $\begin{array}{l}\text { Time } \\
\text { (Hrs) }\end{array}$ & $\begin{array}{c}\text { Ambient } \\
\text { Temp }\left(\mathrm{T}_{\mathrm{a}}\right)^{\circ} \mathrm{c}\end{array}$ & $\begin{array}{c}\text { Glass Inside } \\
\text { Temp }\left(T_{\text {gin }}\right){ }^{\circ} \mathbf{c}\end{array}$ & $\begin{array}{c}\text { Glass Outside } \\
\text { Temp }\left(\mathbf{T}_{\text {gout }}\right)^{\circ} \mathrm{c}\end{array}$ & $\begin{array}{l}\text { Plate } \\
\text { Temp } \\
\left(T_{p}\right)^{\circ} c\end{array}$ & $\begin{array}{c}\text { Water } \\
\text { Temp }\left(T_{w}\right) \\
{ }^{\circ} \mathbf{c}\end{array}$ \\
\hline 6 & 27 & 27.1 & 28.4 & 27.4 & 27 \\
\hline 7 & 28.6 & 28 & 29.1 & 28 & 27.9 \\
\hline 8 & 32.1 & 34.4 & 34.8 & 33.1 & 32.4 \\
\hline 9 & 35 & 44.2 & 36.4 & 40.3 & 37.8 \\
\hline
\end{tabular}




\begin{tabular}{|c|c|c|c|c|c|}
\hline \multicolumn{7}{|c|}{ Table 5.2: Contd., } \\
\hline 10 & 38.2 & 49.1 & 39.3 & 47.8 & 48.2 \\
\hline 11 & 39.6 & 53.9 & 43.1 & 55.1 & 56 \\
\hline 12 & 42.3 & 58.2 & 43.4 & 63.9 & 66.1 \\
\hline 1 & 43.4 & 64.7 & 46 & 69 & 70.1 \\
\hline 2 & 44.8 & 65.5 & 47.2 & 72.1 & 71.8 \\
\hline 3 & 41.1 & 64.8 & 46.1 & 70.8 & 72.4 \\
\hline 4 & 40.5 & 59.2 & 44 & 65.6 & 68.2 \\
\hline 5 & 39.7 & 52 & 41.5 & 56.8 & 60 \\
\hline 6 & 38.4 & 49.2 & 38 & 49.3 & 53.9 \\
\hline
\end{tabular}

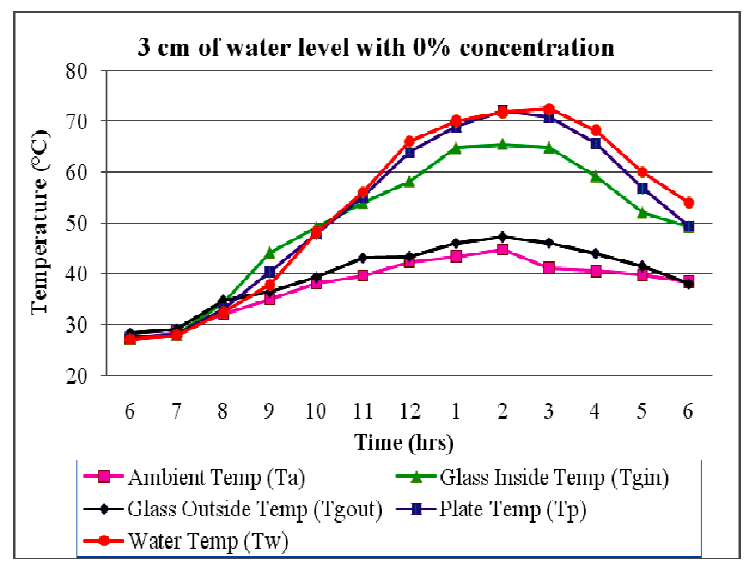

Figure 5.2: Temperature Vs Time for $0 \%$ Salt Concentration (3cm Depth)

Figure 5.2 shows that variation of temperature and time for $3 \mathrm{~cm}$ of water level with $0 \%$ concentration. It can be seen that an increase in the water temperature occurs until it reaches the maximum in the afternoon because the absorbed solar radiation exceeds the losses to the ambient. From about 3 pm, water temperature decreases due to the losses from the solar still which becomes larger than the absorbed solar radiation. It can be noted that the system with heat storage (stone) medium. The maximum temperature of the water is $72.4^{\circ} \mathrm{c}$

\subsection{With Heat Storage Medium (1cm Depth)}

Table 5.3: $1 \mathrm{~cm}$ Depth (3.24 lit of Water with $10 \%(0.36 \mathrm{~g})$ Salt Concentration

\begin{tabular}{|c|c|c|c|c|c|}
\hline $\begin{array}{l}\text { Time } \\
\text { (Hrs) }\end{array}$ & $\begin{array}{c}\text { Ambient } \\
\underset{{ }^{\circ}}{\text { Temp }\left(T_{a}\right)}\end{array}$ & $\begin{array}{c}\text { Glass Inside } \\
\text { Temp }\left(\mathbf{T}_{\text {gin }}\right) \\
{ }^{\circ} \mathrm{c}\end{array}$ & $\begin{array}{c}\text { Glass } \\
\text { Outside } \\
\text { Temp } \\
\left(\mathrm{T}_{\text {gout }}\right)^{\circ} \mathrm{c}\end{array}$ & $\begin{array}{l}\text { Plate } \\
\text { Temp } \\
\left(T_{p}\right)^{\circ} \mathbf{c}\end{array}$ & $\begin{array}{c}\text { Water } \\
\text { Temp }\left(T_{w}\right) \\
{ }^{\circ} \mathbf{c}\end{array}$ \\
\hline 6 & 26.4 & 25 & 26.8 & 26 & 25.8 \\
\hline 7 & 27.2 & 27.6 & 28.1 & 27.2 & 27 \\
\hline 8 & 31.5 & 32 & 33.4 & 31.8 & 30.3 \\
\hline 9 & 34 & 40.1 & 36.6 & 40 & 39.6 \\
\hline 10 & 37.8 & 52.1 & 44.8 & 52.2 & 55.8 \\
\hline 11 & 39.1 & 56 & 47.7 & 57.8 & 65.1 \\
\hline 12 & 41.8 & 61.8 & 48.4 & 66.1 & 70.3 \\
\hline 1 & 47.2 & 64.1 & 50 & 68.2 & 72.4 \\
\hline 2 & 43.4 & 65.6 & 47.1 & 70.1 & 72.8 \\
\hline 3 & 41.8 & 66.9 & 46.8 & 71.8 & 73.1 \\
\hline 4 & 39.7 & 61.8 & 46 & 68.5 & 70 \\
\hline 5 & 37.1 & 50.3 & 40.1 & 55.7 & 59.8 \\
\hline 6 & 35 & 43.2 & 37.8 & 46.3 & 47.1 \\
\hline
\end{tabular}




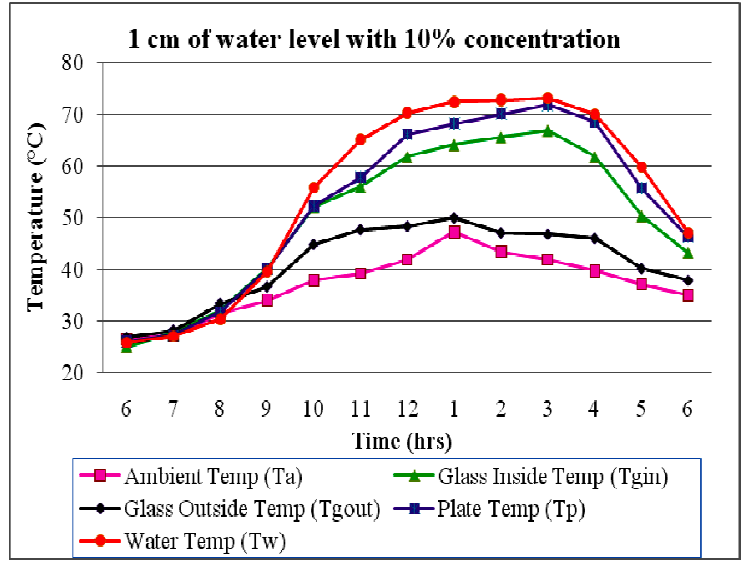

Figure 5.3: Temperature Vs Time for $10 \%$ Salt Concentration (1cm Depth)

Figure 5.3 shows that variation of temperature and time for $1 \mathrm{~cm}$ of water level with $10 \%$ concentration. It can be seen that an increase in the water temperature occurs until it reaches the maximum in the afternoon because the absorbed solar radiation exceeds the losses to the ambient. From about $3 \mathrm{pm}$, water temperature decreases due to the losses from the solar still which becomes larger than the absorbed solar radiation. It can be noted that the system with heat storage (stone) medium. The maximum temperature of the water is $73.1^{\circ} \mathrm{c}$

\subsection{With Heat Storage Medium (3cm Depth)}

Table 5.4: $3 \mathrm{~cm}$ Depth $(9.72$ lit of Water with $10 \%(1.08 \mathrm{~kg})$ Salt Concentration

\begin{tabular}{|c|c|c|c|c|c|}
\hline $\begin{array}{l}\text { Time } \\
\text { (Hrs) }\end{array}$ & $\begin{array}{c}\text { Ambient } \\
\text { Temp }\left(T_{\mathrm{a}}\right) \\
{ }^{\circ} \mathbf{c} \\
\end{array}$ & \begin{tabular}{|c} 
Glass Inside \\
Temp $\left(\mathbf{T}_{\text {gin }}\right)$ \\
${ }^{\circ} \mathbf{c}$
\end{tabular} & $\begin{array}{c}\text { Glass Outside } \\
\text { Temp }\left(\mathbf{T}_{\text {gout }}\right) \\
{ }^{\circ} \mathbf{c}\end{array}$ & $\begin{array}{l}\text { Plate } \\
\text { Temp } \\
\left(\mathrm{T}_{\mathrm{p}}\right)^{\circ} \mathrm{c} \\
\end{array}$ & $\begin{array}{c}\text { Water } \\
\text { Temp } \\
\left(\mathrm{T}_{\mathrm{w}}\right)^{\circ} \mathrm{c}\end{array}$ \\
\hline 6 & 28.8 & 28.1 & 28.3 & 29 & 29.1 \\
\hline 7 & 30.1 & 30.3 & 30 & 29.8 & 28.8 \\
\hline 8 & 32 & 34.5 & 35.1 & 32.3 & 31 \\
\hline 9 & 33.8 & 35.8 & 36.3 & 33.8 & 32.8 \\
\hline 10 & 34.7 & 49.1 & 40.5 & 48 & 49.3 \\
\hline 11 & 38.6 & 53 & 43.8 & 57.4 & 60.1 \\
\hline 12 & 41.3 & 62.3 & 44.9 & 65.7 & 68.9 \\
\hline 1 & 43.2 & 63.6 & 47.1 & 67.5 & 70.4 \\
\hline 2 & 46.8 & 66.8 & 51 & 72.7 & 73.5 \\
\hline 3 & 47.1 & 64.1 & 50.5 & 68.4 & 70 \\
\hline 4 & 43.6 & 58 & 48.7 & 62.6 & 62.3 \\
\hline 5 & 38 & 51.1 & 42.3 & 55.3 & 57.1 \\
\hline 6 & 35.4 & 43.2 & 38.1 & 46 & 48 \\
\hline
\end{tabular}




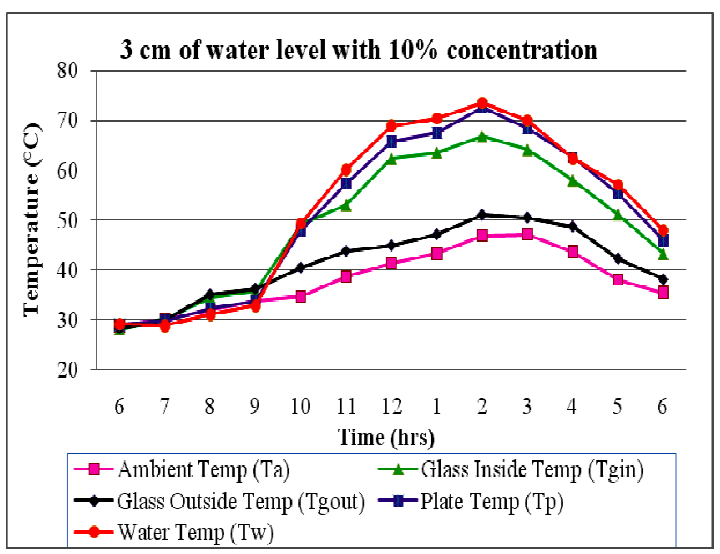

Figure 5.4: Temperature Vs Time for $10 \%$ Salt Concentration (3cm Depth)

Figure 5.4 shows that variation of temperature and time for $3 \mathrm{~cm}$ of water level with $10 \%$ concentration. It can be seen that an increase in the water temperature occurs until it reaches the maximum in the afternoon because the absorbed solar radiation exceeds the losses to the ambient. From about 2 pm, water temperature decreases due to the losses from the solar still which becomes larger than the absorbed solar radiation. It can be noted that the system with heat storage (stone) medium. The maximum temperature of the water is $73.5^{\circ} \mathrm{c}$

\subsection{Productivity Vs Time with Various Concentrations}

\subsection{1 $1 \mathrm{~cm}$ Depth of Water Level}

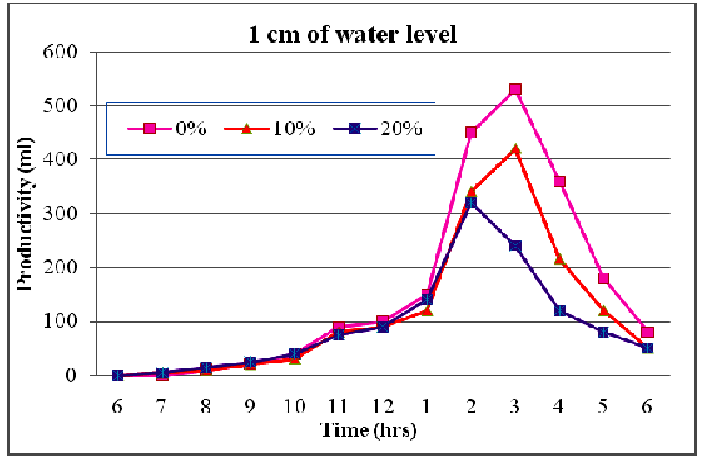

Figure 5.2.1: Productivity Vs Time for Various Concentrations (without Heat Storage Medium)

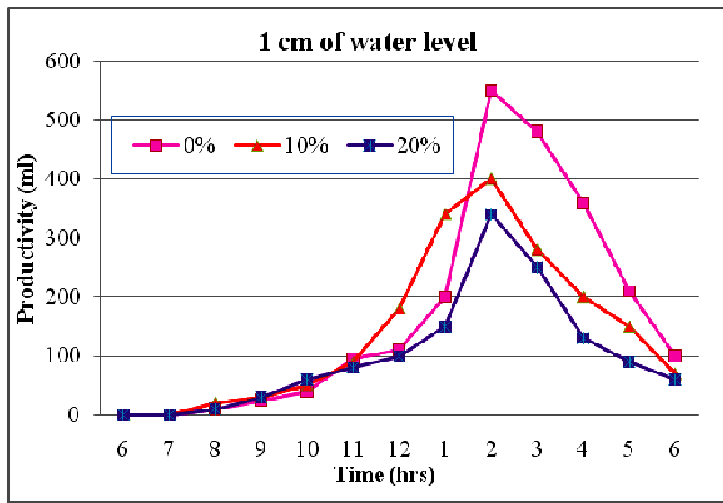

Figure 5.2.2: Productivity Vs Time for various concentrations (with heat storage medium)

Figure 5.2.1 and 5.2.2 shows the variation of temperature and productivity for $1 \mathrm{~cm}$ of water level without and with heat storage (stone) medium. The comparison of the above graph noted the productivity is higher than that of without 
heat storage medium

\subsubsection{3cm Depth of Water Level}

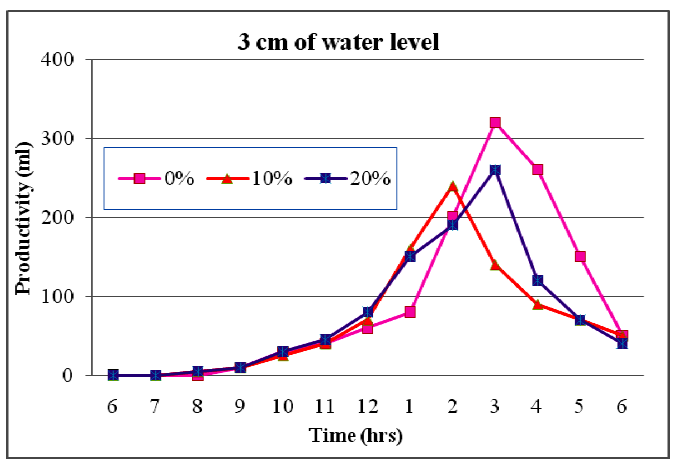

Figure 5.2.3: Productivity Vs Time for Various Concentrations (without Heat Storage Medium)

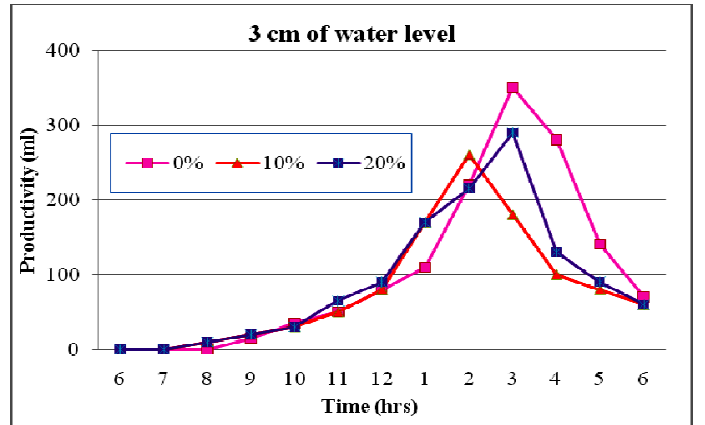

Figure 5.2.3: Productivity Vs Time for Various Concentrations (with Heat Storage Medium)

Figure 5.2.2 and 5.2.3 shows the variation of temperature and productivity for $3 \mathrm{~cm}$ of water level without and with heat storage (stone) medium. The comparison of the above graph noted that the productivity is higher than that of without heat storage medium.

\section{CONCLUSIONS}

In this present study, several conclusions can be obtained. The productivity of the system with heat storage medium (stone) and without heat storage medium results was compared. Productivity is higher than that of the system of without heat storage (stone) medium, and also the temperature values are increased. The water depth decreases from higher to lower, the productivity values are increased. The comparison of the maximum temperature and productivity with a storage medium (stone) and without heat storage medium are tabulated below.

Table 6.1: Comparison of Maximum Temperature and Maximum Productivity

\begin{tabular}{|c|c|c|c|c|c|}
\hline \multirow[b]{2}{*}{ S. No } & \multirow{2}{*}{$\begin{array}{c}\text { Various } \\
\text { Conditions }\end{array}$} & \multicolumn{2}{|c|}{$\begin{array}{c}\text { Without Heat Storage } \\
\text { Medium }\end{array}$} & \multicolumn{2}{|c|}{$\begin{array}{l}\text { With Heat Storage } \\
\text { Medium (stone) }\end{array}$} \\
\hline & & $\begin{array}{l}\text { Maximum } \\
\text { Temp }\left({ }^{\circ} \mathbf{c}\right)\end{array}$ & \begin{tabular}{|c|} 
Maximum \\
Productivity \\
$(\mathrm{ml})$
\end{tabular} & $\begin{array}{l}\text { Maximum } \\
\text { Temp }\left({ }^{\circ} \mathrm{c}\right)\end{array}$ & \begin{tabular}{|c} 
Maximum \\
Productivity \\
$(\mathrm{ml})$
\end{tabular} \\
\hline 1 & $\begin{array}{l}1 \mathrm{~cm} \text { with } 0 \% \\
\text { salt } \\
\text { concentration }\end{array}$ & 76.4 & 530 & 77.2 & 550 \\
\hline 2 & $\begin{array}{l}3 \mathrm{~cm} \text { with } 0 \% \\
\text { salt } \\
\text { concentration }\end{array}$ & 71.7 & 320 & 72.4 & 350 \\
\hline
\end{tabular}




\begin{tabular}{|c|c|c|c|c|c|}
\hline \multicolumn{6}{|c|}{ Table 6.1: Contd., } \\
\hline 3 & $\begin{array}{l}5 \mathrm{~cm} \text { with } 0 \% \\
\text { salt } \\
\text { concentration }\end{array}$ & 66.8 & 280 & 68.7 & 300 \\
\hline 4 & $\begin{array}{l}1 \mathrm{~cm} \text { with } 10 \% \\
\text { salt } \\
\text { concentration }\end{array}$ & 72.6 & 400 & 73.1 & 420 \\
\hline 5 & $\begin{array}{l}3 \mathrm{~cm} \text { with } 10 \% \\
\text { salt } \\
\text { concentration }\end{array}$ & 71.2 & 240 & 73.5 & 260 \\
\hline 6 & $\begin{array}{l}5 \mathrm{~cm} \text { with } 10 \% \\
\text { salt } \\
\text { concentration }\end{array}$ & 61.4 & 230 & 63.5 & 240 \\
\hline 7 & $\begin{array}{l}1 \mathrm{~cm} \text { with } 20 \% \\
\text { salt } \\
\text { concentration }\end{array}$ & 73.1 & 320 & 75.1 & 340 \\
\hline 8 & $\begin{array}{l}3 \mathrm{~cm} \text { with } 20 \% \\
\text { salt } \\
\text { concentration }\end{array}$ & 74.8 & 260 & 76.8 & 290 \\
\hline 9 & $\begin{array}{l}5 \mathrm{~cm} \text { with } 0 \% \\
\text { salt } \\
\text { concentration }\end{array}$ & 66.7 & 240 & 68.4 & 250 \\
\hline
\end{tabular}

\section{REFERENCES}

1. Julián Blanco Gálveza et. al, Seawater desalination by an innovative solar-powered membrane distillation system, Elsevier, Desalination 246 (2009) 567-576.

2. Shaobo Houa. $b$ Two-stage solar multi-effect humidification dehumidification desalination process plotted from pinch analysis, Elsevier, Desalination 222 (2008) 572-578.

3. Yasser fathi Nassar et. al, The second generation of the solar desalination systems, Elsevier, Desalination 209 (2007) 177-181.

4. Shalabh C. Marooa et. al, Theoretical analysis of a single-stage and two-stage solar driven flash desalination system based on passive vacuum generation, Elsevier, Desalination 217 (2009) 17-28.

5. Fawzi Banat et. al, Exergy analysis of desalination by solar-powered membrane distillation units, Elsevier, Desalination 230 (2008) 27-40.

6. Fawzi Banata et. al, Performance evaluation of the "large SMADES" autonomous desalination solar-driven membrane distillation plantin Aqaba, Jordan, Elsevier, Desalination 217 (2007) 17-28.

7. Fawzi Banat et. al, Economic evaluation of desalination by small-scale autonomous solar-powered membrane distillation units, Elsevier, Desalination 220 (2008) 566-573.

8. Omar O. Badran et. al, Evluating thermal performance of a single slope solar still, springer, heat mass transfer (2007) 43:985-995.

9. Thilak, K., Kiruthika, R., \& Sakthivel, M. Experimental And Analytical Study Of Roof Heat Effect On The Performance Of Solar Desalination System.

10. Hazim Mohameed Qiblawey et. al, Solar thermal desalination technologies, Elsevier, Desalination 220 (2008) 633-644.

11. Hassan E. S. Fatha et. al, PV and thermally driven small-scale, stand-alone solar desalination systems with very low maintenance needs, Elsevier, Desalination 225 (2008) 58-69. 